\title{
LARANGAN PENYEDIAAN TEMPAT BAGI PENJUAL BARANG HASIL PELANGGARAN HAK CIPTA GUNA MEWUJUDKAN NILAI KEADILAN
}

\section{Tri Minarti}

\author{
Fakultas Hukum Universitas Kapuas Sintang \\ Jalan Yc. Oevang Oeray 92 Sintang \\ Email : triminartianwar@gmail.com
}

\begin{abstract}
One of the functions of the law is to bring about justice, the creators and holders of copyrights have always demanded justice for their economic rights which have been violated by sellers or multipliers of goods resulting from copyright infringement. UUHC No. 28 of 2014 contains new provisions that have never been regulated, namely related to the prohibition of providing a place for the seller of goods resulting from copyright infringement, precisely in Article 10 of UUHC No. 28 of 2014. Therefore the author is interested in examining the true provisions of UUHC No. 28 of 2014 was made to realize justice for the creators / holders of copyright related.
\end{abstract}

This research method is included in the normative juridical research domain. The research data is obtained by studying library materials, which are then systematized and then analyzed, until conclusions are generated. The results showed that the provisions of Article 10 of UUHC No. 28 of 2014 concerning the prohibition of managers of trade places from allowing the sale / duplication of goods resulting from copyright infringement and / or related rights in the place of trade they manage. The law has indeed provided justice for the creator or owner of the copyright one of which is a form of protection of the copyrighted work and especially in terms of obtaining the economic rights of the creator and the holder of the copyright. Bearing in mind that many trading place managers do not yet know the provisions of Article 10 of UUHC No. 28 of 2014, these provisions must be socialized by the Minister of Law and Human Rights, the Department of Industry and Trade as well as the POLDA of Special Criminal Investigators and can be through the installation of banners and pamphlets and broadcast in newspapers and social media.

Keywords: prohibition, Copyright Infringement, Fair Value
Abstrak
Salah satu fungsi hukum adalah untuk mewujudkan keadilan, para pencipta dan pemegang hak cipta selama ini selalu menuntut keadilan atas hak ekonomi mereka yang banyak dilanggar oleh para penjual atau 
pengganda barang hasil pelanggaran

hak cipta. UUHC No. 28 Tahun 2014

telah memuat ketentuan baruyang tidak pernah diatur yaitu terkait dengan larangan penyediaan tempat bagipenjual barang hasil pelanggaran Hak Cipta, tepatnya pada Pasal 10 Di dalamUUHC No. 28 Tahun 2014 . Oleh sebab itu penulis tertarik untuk menguji benarkah ketentuan UUHC No. 28 Tahun 2014 dibuat untuk mewujudkan keadilan bagi para pencipta/pemegang hak cipta terkait.

Metode penelitian ini masuk dalam ranah penelitian yuridis normatif. Datapenelitian diperoleh dengan cara mempelajari bahan pustaka, yang kemudiandisistematisasi dan selanjutnya dianalisis, hingga dihasilkan kesimpulan.

Hasil penelitian menunjukan bahwa ketentuan Pasal 10 UUHC No. 28 Tahun2014 tentang larangan para pengelola tempat perdagangan membiarkanpenjualan/ penggandaan barang hasil pelanggaran hak cipta dan/atau hak terkait ditempat perdagangan yang dikelolanya. Hukum memang telah memberikankeadilan bagi pencipta atau pemilik hak cipta salah satunya bentuk perlindungandari karya cipta dan terutama dalam hal diperolehnya hak ekonomi pencipta danpemegang hak cipta. Mengingat banyak pengelola tempat perdagangan yangbelum mengetahui ketentuan Pasal 10
UUHC No. 28 Tahun 2014 maka,ketentuan tersebut haruslah disosialisasikan oleh Menteri Hukum dan Ham, Dinas Perindustrian dan Perdagangan serta POLDA Penyidik Reserse Kriminal Khusus dan dapat melalui $\begin{array}{cl}\text { pemasangan } & \text { spanduk dan } \\ \text { pamflet } & \begin{array}{l}\text { serta } \\ \text { parta }\end{array}\end{array}$

menyiarkan dikoran maupun media sosial.

Kata Kunci : larangan , Pelanggaran Hak Cipta, Nilai Keadilan

\section{Pendahuluan}

Di pusat-pusat perbelanjaan mudah ditemukan barang- barang hasil pelanggaran hak cipta seperti film,lagu, dan lain -lain yang disimpan dalam Compact Disk (CD) baik yang dijualdengan cara sembunyisembunyi maupun secara terang-terangan. Perbedaanharga yang cukup mencolok antara barang hasil pelanggaran hak cipta yangdijual dengan harga yang jauh lebih murah dibandingkan dengan barang asliyang dijual dengan harga yang lebih mahal telah menarik minat konsumenuntuk membeli barang hasil pelanggaran hak cipta tersebut.

Menurut ketentuan hukum yang berlaku, hak cipta merupakan hak ekslusif yaang bermakna tidak ada pihak lain yang dapat memanfaatkan hak tersebut tanpa izin pencipta. Dengan demikian, setiap perbanyakan atau penggandaan suatu karya cipta termasuk juga peredaran dan penjualannya harus seizin dari 
Tri Minarti, Larangan Penyediaan Tempat Bagi Penjual Barang Hasil Pelanggaran Hak Cipta 83 juga

pemegang hak ekslusif. Hak ekslusif

dimiliki olehpemegang hak cipta yang bukan pencipta namun terbatas pada hak ekonomi suatu karya cipta saja Izin yang diberikan oleh pemegang hak cipta biasa disebut dengan istilah lisensi yaitu izin tertulis yang diberikan oleh pemegang hak atau pemilik hak terkait kepada pihak lain untuk melaksanakan hak ekonomi atas ciptaanya atau produk hak terkait dengan syarat tertentu. Perbanyakan atau penggandaan, peredaran serta penjualan hak tanpa izin adalah suatu bentuk pelanggaran atas

hak ekslusif dari pemegang hak cipta.

Hal ini dapat menimbulkan kerugian bagi pemegang

hak cipta karena ia tidak dapat memperoleh manfaat dari hak ekonomi tersebut.

Hukum telah memberikan perlindungan atas hak ekonomi pencipta atau pemegang hak cipta dan semakin ditingkatkan dari masa ke masa. Undangundang No. 28 tahun 2014 tentang Hak Cipta (UUHC) bahkan melibatkan pengelola tempat perdagangan untuk turut melindungi pemegang hak cipta. Pasal 10 UUHC No. 28 tahun 2014 menyebutkan bahwa pengelola tempat perdagangan dilarang membiarkan penjualan dan/atau penggandaan barang hasil pelanggaran Hak Cipta dan/ atau Hak Terkait di tempat perdagangan yang dikelolanya. Dengan demikian, apabila di tempat perdagangan yang dikelolanya terdapat penjualan dan/atau pelanggaran hak cipta atau hak terkait pedagang kaki lima, maka pengelola tempat perdagangan dapat dimintai pertanggungjawabannya atas para penjual.

Ketentuan pasal 10 UUHC No. 28 tahun 2014 telah lebih memberikan perlindungan terhadap pencipta atau pemegang hak cipta dibandingkan dengan UU sebelumnya,

Ketentuan pasal ini dapat dikatakan lebih memberikan rasa keadilan kepada pencipta dan pemegang hak cipta atas berbagai tindakan pelanggaran hak ekonomi atas suatu ciptaan. Ketentuan ini juga dimaksudkan agar para pengelola tempat perdagangan lebih menghargai hasil karya para

pencipta. Dengan demikian 
cipta illegal tidak hanya bertumpu pada pihak pengganda maupun penjual saja.

Subekti 33 mengatakan bahwa hukum antara lain bertujuan untuk, melayani tujuan negara itu dengan mengadakan keadilan dan ketertiban, Ditegaskan selanjutnya bahwa keadilan biasa digambarkan sebagai sebuah keadaan keseimbangan yang dapat membawa ketentraman dalam hati setiap orang, dan kalau terusik atau dilanggar maka akan dapat memunculkan kegoncangan dan kegelisahan. Demikian juga dengan para pencipta atau

33 Lihat Subekti dalam Esmi Warasih, 2014, Pranata Hukum Sebuah Telah Sosiologis, Penerbit Pustaka Magister, Semarang, h. 21. 
pemegang hak cipta yang juga akan terusik apabila hak-haknya dilanggar.

Keadilan akan selalu memiliki kandungan berupa unsur "penghargaan,penilaian, pertimbangan dan karena ini ia lazim disimbolkan dengan neraca keadilan. Dikatakan bahwa keadilan tersebut menuntut bahwa dalam keadaan yang sama maka tiap orang mesti menerima bagian yang sama juga". Bahwa konteks keadilan dikaitkan dengan hak cipta adalah perolehan hak ekonomi pencipta. Keadilan tercapai apabila sama-sama menguntungkan semua yang terlibat dalam proses mendapatkan hak ekonomi suatu ciptaan.

Pengelolatempat perdagangan adalah salah satu pihak yang terlibat di dalamnya. Pengambilan dengan tidak memberikan kompensasi bagi pemiliknya sama seperti para pembajak / penggada adalah suatu tindakan yang tidak dapat dibenarkan karena melanggar ajaran moral yang baik. Landasan moral ini pula yang dikenal dengan teori filsafat sebagai teori hukum alam. Dalam ajaran moral dikenal doktrin " jangan mencuri atau jangan mengambil apa yang bukan hak mu". Jadi apabila pengelola tempat perdagangan membiarkan para pembajak/ pengada menjual hasil pelangaran hak cipta berarti pengelola tempat tersebut telah mendukung hal ini terjadi, dengan demikian keadilan bagipencipta tidak akan pernah tercapai Sebuah teori yang sering dipakai dalam kaitan dengan hak cipta yaitu teori hukum alam dimana suatu tindakan dapat diukur dengan moral, dengan demikian apabila melakukan pelanggaran sudah pasti tidak dapat dibenarkan karena melanggar ajaran moral yang baik. Dalam ajaran moral dikenal doktrin jangan mencuri atau jangan mengambil apa yang bukan hakmu. Dikarenakan pengambilan seperti itu dianggap cara yang tidak bermoral dengan tidak memberikan kompensasi bagi pemiliknya. Para Pembajak/ pengada telah menjual hasil pelanggaran hak cipta tanpa memberikan kompensasi kerpada pencipta. Namun para pembajak/pengadaan tersebut membayar uang sewa tempat kepada pengelola tempat perdagangan, dengan demikian pengelola tempat perdagangan telah menfasilitas dan bahkan mendukung adanya pelanggarn hak bagi pencipta. Adanya pelanggaran hak bagi pencipta membuat pencipta tidak mendapatkan apa yang menjadi haknya Jadi disini tidak terdapat keadilan bagi pencipta. Bertitik tolak dari uraian pada latar belakang masalah tersebut di atas, maka yang menjadi permasalahan dalam penelitian ini adalah Benarkahlarangan penyediaan tempat bagi penjual barang hasil pelanggaran Hak Ciptadibuat untuk mewujudkan nilai keadilan? Agar tidak terjadi kerancuan tentang 
konsep-konsep yang dipergunakan dalam penelitian ini, maka perlu penulis kemukakan bahwa yang penulis maksud dengan yaitu: Pertama Hak cipta, untuk konsep hak cipta penulis mengacu pada

Undang-Undang Nomor 28 Tahun 2014 Mengenai Hak Cipta, menyebutkan Hak Cipta adalah hak eksklusif pencipta yang timbul secara otomatis berdasarkan prinsip deklaratif setelah suatu ciptaan diwujudkan dalam bentuk nyata tanpa mengurangi pembatasan sesuai dengan ketentuan peraturan perundang-undangan. Konsep UUHC inilah yang dipenulis gunakan dalam penelitian ini.

Kedua pengelola tempat perdangangan, menurut Kamus Besar Bahasa Indonesia, "Pengelola yaitu orang yang mengelola". Sedangan "tempat yaitu sesuatu yang dipakai untuk menaruh (menyimpan, meletakan dan sebagainya); wadah. Perdagangan yaitu dagang; urusan dagang; perniagaan". Serta "Penjual yaitu orang yang menjual". Dengan demikiankonsep yangpenulis maksudkan dengan pengelola tempat perdagangan dalam penelitian ini adalah orang yang menyediakan tempat untuk urusan dagang.

Perilaku yang menyimpang untuk melakukan tindakan menurut kehendak sendiri tanpa memperhatikan peraturan hak cipta yang telah di buat. Ketiga, pelanggaran hak cipta adalah penggunaan karya berhak cipta yang melanggar hak ekslusif

pemegang hak cipta, seperti hak untuk memproduksi, mendistribusi, menampilkan atau memamerkan karya berhak cipta atau membuat karya turunan, tanpa izin dari pemegang hak cipta, yang biasanyapenerbit atau usaha lain yang mewakili atau ditugaskan oleh pencipta karya tersebut.34

Suatu perbuatan dapat dikatakan sebagai suatu pelanggaran hak cipta apabila perbuatan tersebut melanggar hak khusus dari pencipta atau pemegang hak cipta. ${ }_{35}$ Umumnya hak cipta dilanggar jika materi hak cipta tersebut digunakan tanpa izin dari pencipta yang mempunyai hak eksklusif atas ciptaannya.36

Keempat keadilan Menurut Kahar

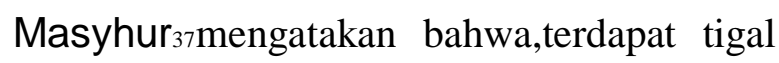
hal tentang pengertian adil, yaitu:

1. "Adil" ialah : meletakan sesuatu pada tempatnya.

2. "Adil" ialah : menerima hak tanpa lebih dan memberikan orang lain tanpa kurang.

3. "Adil" ialah : memberikan hak setiap yang berhak secara lengkap tanpa lebih tanpa kurang antara sesama

34 Id.wikipedia.org/wiki/Pelanggaran-hakcipta, diakses pada hari Rabu tanggal 3 Agustus 2016, Pukul 18.40 WIB.

35 Adrian Sutedi, 2009, Hak Atas Kekayaan Intelektual, Sinar Grafika, Jakarta, h. 120.

36 Asian Law Group Pty. Ltd, 2011, Hak Kekayaan Intelektual Suatu Pengantar, PT. Alumni, Bandung, h. 122.

37 Kahar Masyhur, 1985, Membina Moral dan Akhlak, Kalam Mulia, Jakarta,h. 71. 
86 Perahu, Volume 7 Nomor 2, September 2019, Hlm 81-89

yang berhak dalam keadaan yang sama, dan penghukuman orang jahat atau yang melanggar hukum, sesuai dengan kesalahan dan pelanggaran”.

Dengan mengacu pada pendapat Kahar Masyhur tersebut, maka konsep adil dalam tulisan ini adalah memberikan hak setiap yang berhak secara lengkap tanpa lebih tanpa kurang antara sesama yang berhak dalam keadaan yang sama, dan penghukuman orang jahat atau yang melanggar hukum, sesuai dengan kesalahan dan pelanggaran.

\section{Metode Penelitian}

Adapun metode yang digunakan yaitu pendekatan normatif adalah suatu penelitian yang dilakukan dengan cara meneliti bahan pustaka atau data sekunder,38 Jenis data di dalam penelitian yaitu Bahan hukum primer yaitu data yang diperoleh langsung dari kehidupan masyarakat dan bahan hukum sekunder yaitu data yang diperoleh dari studi kepustakaan.

Pembahasan

Hukum dapat berperan sebagai alat pengatur atau pengontrol dan dapat pulaberperan sebagai alat rekayasa/perubahan social, bahkan ahli sociologicaljurisprudence, Rosce Pound sangat yakin bahwa hukum dapat menjadi alat untukmengubah masyaarkat

\footnotetext{
38 Ronny Hanintijo Soemitro, 1988, Metodologi Penelitian Hukum dan Jurimetri, Ghalia Indonesia, Jakarta h. 40 .
}

kearah yang lebih baik.39

Hukum dianggap berhasil apa bila telah memenuhi nilai keadilan,kemanfaatan dan kepastian. Maka terkait dengan hak cipta hukum memberikanperlindungan untuk membatasi perilaku-perilaku setiap individu agar tidakmelakukan sikap yang sewenang-wenang terhadap karya cipta dan hanya memberikan haknya kepada pencipta/ pemegang hak cipta saja serta hak ciptatersebut dapat dialihkan sesuai dengan kententuan yang diberlakukan yang agarnilai keadilan tersebut tercapai. Karya cipta merupakan kekayaan intelektual darikreatifitas yang dihasilkan dari olah pikir manusia, curahan tenaga karsa, dansegala jerih payah itu menjadi ktribusi yang memililk nilai ekonomi, oleh karenaitu setiap karya cipta diakui dan dilindungi baik secara moral maupun secarahukum atas sikap pengakuan dan penghormatan.Karya cipta sangat memiliki peran yang sangat penting di dalam kehidupan sehari-hari. Hasil ciptaan dapat berbentuk seperti software, buku, potret, kaset/CD/ DVD yang memberikan berbagai manfaat bagi kehidupan yaknimempercepat dan mempermudah suatu pekerjaan seseorang baik dalam bidangpendidikan maupun yang lain serta dapat digunakan untuk mengakses informasidari segala penjuru dunia, 39 Soerjono Soekanto, 2012, Pokok-pokok Sosiologi Hukum, Jakarta, PT. Raja GrafindoPersada, h. 126. 
Tri Minarti, Larangan Penyediaan Tempat Bagi Penjual Barang Hasil Pelanggaran Hak Cipta 87

memberikan hiburan bahkan masih banyak ciptaanlainnya yang memberikan manfaat. Sehingga hukum memberikan Hak ekslusif terdiri dari hak ekonomi dan hakmoral. Dalam hak ini yang menjadi sering menjadi sorotan yaitu Hak ekonomi,hak ekonomi merupakan hak ekslusif pencipta atau pemegang hak cipta untukmendapatkan manfaat ekonomi atas

ciptaannya berupa royalt.

Nilai ekonomi dari karya cipta membuat orang yang bukan pemilik karyacipta tersebut menjadi tergiur untuk melakukan memperbanyak, menjiplakan danmembajakan. Padahal dalam ketentuan sebelumnya sudah cetuskan. Selainpencipta orang lain tidak berhak atasnya kecuali atas izin pencipta.Memperbanyak, menjiplak dan membajak tanpa adanya izin sama halnya denganpelanggaran hak cipta. Perbuatan tersebut dilakukan semata- mata untukmemperoleh keuntungan ekonomi. Pada dasarnya pelanggaran hak cipta bertujuaningin mencari keuntungan financial secara cepat dengan mengabaikankepentingan pencipta. Jadi dengan adanya pelanggaran hak keadilan bagi pencipta/pemegang hak tidak terpenuhi, sehingga undang-undang sebelumnya dianggap belum berlakuoptimal dan kurang efektif di dalam masyarakat dengan melihat pendapat Paul dan Dias mengajukan 5 syarat yang harus dipenuhi untuk mengefektifitkan sistemhukum yaitu;40

1. Mudah tidaknya makna aturan-aturan hukum itu untuk ditangkap dandipahami;

2. Luas tidaknya kalangan di dalam masyarkat yang mengetahui isi aturanaturanhukum yang bersangkutan;

3. Efesian dan efektif tidaknya mobilitas aturan-aturan hukum;

4. Adanya mekanisme penyelesaian sengketa yang tidak hanya mudahdijangkau dan dimasuki oleh setiap warga masyarakat melainkan jugaharus cukup efektif dalam menyelesaikan sengketa-sengketa, dan;

5. Adanya anggapan dan pengakuan yang merata di kalangan wargamasyarakat bahwa aturan dan pranata-pranata hukum itu memangsesungguhnya berdaya kemampuan yang efektif.

Ketentuan di dalam pasal 10 UUHC No. 28 Tahun 2014 yang berbunyipengelola tempat perdagangan dilarang membiarkan

penjualan/penggandaanbarang hasil pelanggaran hak cipta dan/atau hak terkait di tempat perdaganganyang dikelolanya. Dengan melibatkanpengelolatempatagarparapencipta ataupemegang hak cipta merasa karya ciptanya dilindungi sudah memberikankontribusi yang baik. Perlindungan tersebut merupakan bentuk dari nilai keadilanyang merupakan tujuan dari sebuah hukum, dengan demikian

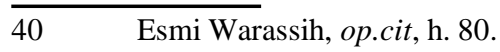


agar sesuatu yangmenjadi hak pencipta dan pemegang hak cipta dapat diperoleh. Ketentuan di dalam undang-undang memang telah mengandung nilaikeadilan terutama bagi pencipta atau pemegang hak cipta, akan tetapi bagaimanadi dalam masyarakat, mengingat harga ved asli cukup tinggi membuat parakalangan masyarakat tidak mampu untuk membelinya. Dengan ini, adanyapenjualan bajakan memberikan kemudahan kepada masyarakat serta merasakebutuhan akan hiburan terpenuhi. Tidak hanya itu adanya pelanggaran hak ciptatelah menjadi budaya masyarakat setempat, sehingga tidak mudah untukmenghilangkan budaya

tersebut di dalam masyarakat. Bagi pencipta danpemegang hak cipta keadilan berwujud sebuah perlindungan atas karya yangmereka hasilkan. Karya cipta yang memilki nilai ekonomi yang dinilai tinggiseperti compact disc membuat masyarakat tidak mampu membelinya dalambentuk asli. Masyarakat berpendapat dengan adanya vcd bajakan mereka merasaterbantu dapat menikmati karya-karya ciptaan seperti film, music dan lain-lain,

akan tetapi hal tersebut tetaplah bertentangan dengan undang-undang.

\section{Simpulan}

Tidak membiarkan para penjual/ atau pengganda yang menjual ved bajakan di sepanjang tempat perdagangan, para pengelola tempat telah memberikan perlindungan bagi karya cipta si pencipta dan pemegang hak cipta hal tersebut dilakukan agar hak ekonomi mereka terpenuhi. agar saling menguntungkan sebaik para penjual/ atau pengganda meminta izin kepada pencipta dan pemegang hak cipta sesuai dengan prosedur yang ada. Izin tersebut dilakukan agar tidak adanya pelanggaran hak bagi pihak pencipta dan pemegang hak cipta dan mereka tidak dirugikan.

\section{Daftar Pustaka}

Adrian Sutedi, 2009, Hak Atas Kekayaan Intelektual, Jakarta : Sinar Grafika.

Asian Law Group Pty. Ltd, 2011, Hak Kekayaan

Bandung : PT. Alumni.

Esmi Warasih, 2014, Pranata Hukum Sebuah Telah Sosiologis, Semarang : Penerbit Pustaka Magister.

Kahar Masyhur, 1985, Membina Moral dan Akhlak, Kalam Mulia, Jakarta.

onny Hanintijo Soemitro, 1988, Metodologi Penelitian Hukum dan Jurimetri, Jakarta : Ghalia Indonesia. Soerjono Soekanto, 2012, Pokok-pokok Sosiologi Hukum, Jakarta: PT. Raja Grafindo Persada. 
Tri Minarti, Larangan Penyediaan Tempat Bagi Penjual Barang Hasil Pelanggaran Hak Cipta 89 